\title{
Positioning Malaysia in Medical Tourism: Implication on Economic Growth in ASEAN Integration
}

\author{
Au Yong Hui Nee \\ Universiti Tunku Abdul Rahman \\ auyonghn@utar.edu.my
}

\begin{abstract}
With a rapid growth of medical tourism in the country, the Malaysian Government is under pressure to make the sector of benefit to the public healthcare services. Purpose: This paper attempts to deepen the understanding of the development of medical tourism on destination countries' healthcare systems and the effect toward economy growth. Methodology: Mix methods were applied in the paper with data for the duration of 2000 - 2015 obtained from sources including Malaysia Health Tourism Council (MHTC) and World Bank Indicators. Analysis of the paper includes t-test of gross national products and medical tourism receipts. The paper also shares strategies needed for effective promotion of medical tourism in a medical tourism decision model. Findings: The result shows that ASEAN Economic Community is likely to bring in higher trade volumes in health services. This paper concludes that medical tourism plays an important role in economy by tripling medical tourism receipts to RM900 million in tandem with the economic growth. Limitations: The findings should be interpreted with caution. Practical implications: Upcoming opportunities are potential medical travellers from less advanced ASEAN countries. Social implications: Growth of medical tourism should not lead to 'brain drain'. Originality: The study is one of its kinds as it highlights by the use of mix mode in analysing the sector's economic contribution in a transboundary tourism context in a modified medical tourism model. Limitations: For the qualitative analysis of this paper on top of limited length of data for quantitative analysis, the findings should be interpreted with caution.
\end{abstract}

Keywords: Decision Process, Economic Integration, Healthcare, Education \& Welfare, Health Tourism, Marketing Strategy, Medical Tourism

JEL Classification: F6, I1, M3

\section{INTRODUCTION}

According to Patients Beyond Borders, medical tourism generates US\$40 billion market with expansion rate of 25 per cent a year. Most of these hospital hoppers head to Asian countries. More and more patients from advanced countries are traveling for healthcare to third world countries. Many of these "medical tourists" are not wealthy, but are seeking high quality medical care at affordable prices (Herrick, 2007). Reported in the BangkokPost, Patients Beyond Borders estimated that up to 12 million people worldwide now travel for care, of whom one million of them are Americans. Middle East business rose 
after the Sept 11, 2001 attacks on US targets, due to these patients felt unwelcome in the western countries. According to Medical Tourism Guide 2014, the United Arab Emirates spent over \$2 billion in 2011 to send patients abroad.

Based on information from Indonesian Medical Association, Indonesians spend more than 8.8 trillion Indonesian Rupiah (US\$ 1.0 billion) per year on medical treatments overseas (Frost and Sullivan, 2012). According to the $\mathrm{MOH}$ Vietnam, around 40,000 Vietnamese citizens spend about VND 20.7 trillion (US\$ 1.1 billion) on medical treatment services overseas each year. Indonesians seek healthcare services in foreign countries such as Singapore and Malaysia for better quality healthcare. About the purpose of the health travellers, studies such as Yang et al. (2015) confirmed the effect of tourists' needs for healing experience on behavioural intentions for transformation. Studies from Lee \& Kim (2015) concluded determinants of travelers' decision making for the destination of health tourism are such as distance, cost, language, economy, competency of medical technology, and culture.

Patients Beyond Borders has placed Malaysia among the top ten medical tourism destinations in the world. Four countries in the ASEAN region are in the top destination of medical tourists, Thailand is on the top (Picazo, 2013). Within ASEAN, Malaysia and Singapore have been identified as among the hottest growing markets (Brinker \& Ong, 2014).
There are a host of regulatory restrictions geared toward foreign operators in healthcare services in ASEAN. Only five out of the 10 member states have allowed full foreign ownership in their respective healthcare sectors. Malaysia, the Philippines, and Thailand only allow minority foreign ownership of $30 \%, 40 \%$ and $49 \%$ respectively. Meanwhile, Indonesia's Ministry of Health states a $90 \%$ foreign ownership limit in contradiction to the $100 \%$ limit in the investment policy. Myanmar has recently revised its foreign investment law and provides an $80 \%$ cap on foreign ownership for hospitals and clinics (CARI, 2013). One of the four AEC priority service sectors is healthcare of which the foreign ownership ceiling for ASEAN investors will be raised to $70 \%$. Currently, hospitals in Thailand have only $15 \%$ foreign equity participation on average (Amornvivat, 2012).

With the Association of Southeast Asian Nations (ASEAN) Economic Community (AEC), deeper integration of health services and trade in health services is likely, especially since the health sector is one of the identified priority areas under the ASEAN Framework Agreement on Services (AFAS). In relation, the ASEAN Open Skies agreement initiated by the transport ministers in 2005 to accelerate the liberalization of air travel has allowed regional budget airlines to enter the market and offer more flights between ASEAN destinations. The increased capacity in interregional air transportation facilitated intra-ASEAN travel of 
medical purpose.

Foreign health personnel wishing to practice in Malaysia, Singapore or Thailand must possess a basic qualification, which has to be approved and registered by the relevant bodies to obtain a license. In Thailand, this process is more stringent as foreign practitioners must pass the examination set by the relevant councils in Thai language. The labour movement would be made easier under Mutual Recognition Agreements (MRAs), which aim to facilitate the movement of skilled labour in priority sectors, among which medical personnel are included (Amornvivat, 2012). On the other hand, increased trade liberalization within the health sector, though little regional regulation of the trade exists to promote practices and protections to avoid foreseeable harm and protect the rights of people involved (Whittaker, 2010). Alsharif et al. (2010) warn that the harder task will be how medical tourism as an industry might be regulated on a global scale.

Reported by BERNAMA, Malaysia attracted over 850,000 health travellers in 2015. ("Govt Aims to Generate RM1.3 billion from Medical Tourism Industry This Year", 29 March 2016). Refer Table 1. The number of medical travellers has experienced average annual growth rate of over $7 \%$ between 2011-2015 from 641,000 in 2011 to 850,000 in 2015. According to the Malaysia Healthcare Travel Council (MHTC), those numbers are expected to rise further to break the one-million mark in the next few years (Irsyad, 2016).

Table 1. Healthcare Travellers between 2011-2015

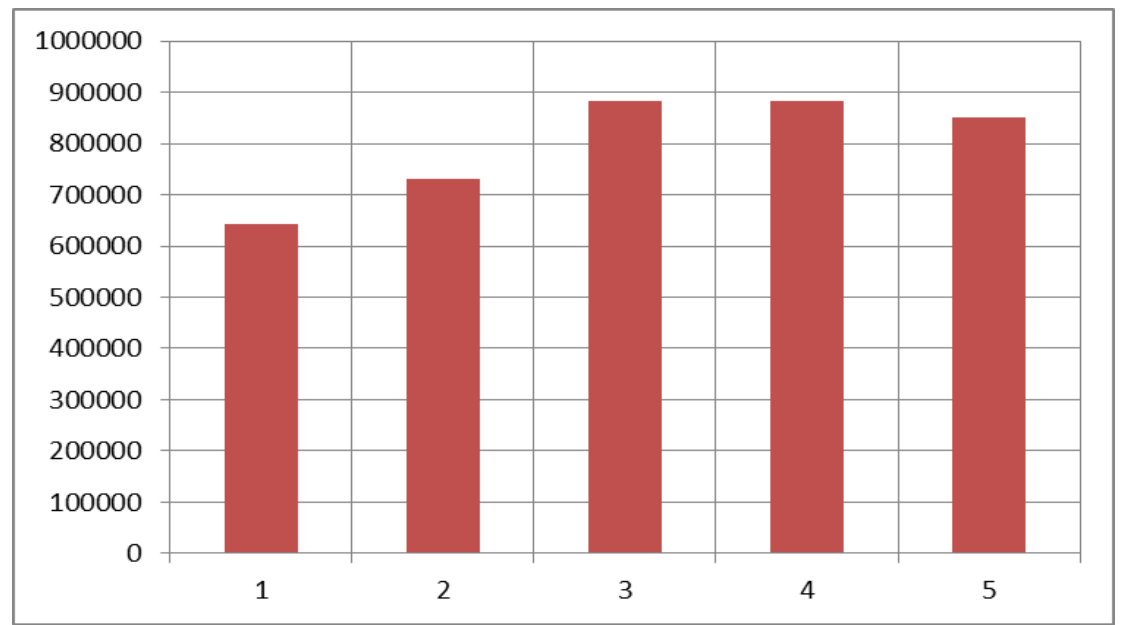

Source: Malaysia Healthcare Travel Council, MHTC (2016)

Refer Table 2. The top ten home-countries for medical tourists in 2011 are Indonesia, India, Japan,
United Kingdom, China \& Hong Kong, US, Australia, Iran, Libya, and Nepal (Suleiman, 2013). 
Table 2. Comparison of Healthcare Travellers from Top 10 Country of Origin

\begin{tabular}{|l|l|c|c|c|}
\hline No. & \multicolumn{1}{|c|}{ Country of Origin } & Healthcare & Travellers & Increase from Previous Year (\%) \\
\hline & & 2010 & 2011 & \\
\hline 1. & Indonesia & 251,177 & 335,150 & 28,32 \\
\hline 2. & India & 16,940 & 18,604 & 9,82 \\
\hline 3. & Japan & 14,937 & 16,111 & 7,85 \\
\hline 4. & United Kingdom & 8,254 & 12,704 & 53,91 \\
\hline 5. & China and Hong Kong & 7,941 & 11,886 & 49,68 \\
\hline 6. & United States & 7,557 & 10,584 & 40,05 \\
\hline 7. & Australia & 7,157 & 9,678 & 35,22 \\
\hline 8. & Iran & 3,374 & 8,836 & 161,88 \\
\hline 9. & Libyan Arab Jamahiriya & 6,008 & 7,225 & 20,25 \\
\hline 10. & Nepal & 3,179 & 6,727 & 111,60 \\
\hline
\end{tabular}

Source: Suleiman (2013)

According to the National Transformation Programme (NTP) Annual Report 2015 as reported by AstroAwani, Malaysia healthcare's strongest markets are Indonesia, consisting 62 percent of total healthcare revenue numbers, followed by the Middle East $(7.4$ percent), India (3 percent), China (2.6 percent), Japan (2.6 percent) and Australia, New Zealand and United Kingdom (2.5 percent), and emerging markets such as China, Central Asia and the greater ASEAN region ("NTP: Malaysia generates RM588 million in healthcare travel revenue", 27 April 2016).

Indonesia is a very important market for Malaysia's medical tourism because of an emerging Indonesian middle class who wish to get their medical treatment abroad. Indonesian health tourists feel comfortable in Malaysia because of common language, foods, religions and the convenience of travel (MPC, 2014). Besides, Malaysia also sought to attract higher-spending medical tourists. The global Muslim consumer base is estimated at 1.8 billion across 100 countries. As a result,
Malaysia is opening up a larger Muslim market share through provision of halal treatments. As reported in The Star, Kuala Lumpur is the destination of choice for Arab tourists ("Malaysia has great potential in medical tourism", 26 September 2012). Reported by the BangkokPost, in 2012 Kuala Lumpur's Prince Court Medical Centre received almost 2,000 health travellers from Libya and more than 1,000 from Iran respectively. ("Malaysia eyes medical-tourism crown", 30 July 2014). There is an increasing number of medical travellers from the GCC countries including Oman coming to Malaysia for its value-for-money, high quality care and competitive pricing. The number of healthcare travellers coming from the GCC countries to Malaysia had increased from 10,000 in 2012 to 11,000 in 2013 while medical travellers from Oman had an encouraging growth of $30 \mathrm{pc}$ from 1,000 in 2012 to 1,300 in 2013 ("Oman Observer, Malaysia continues to attract more medical tourists from GCC countries", 8 September 2014). 
On the other hand, Singaporeans are able to use their Central Provident Fund savings and insurance at hospitals, contributing to the rise in medical tourism (International Medical Travel Journal, 29 June 2015). In Singapore, 93\% of the population is covered by Medi-Shield. In addition, Singaporeans have been allowed to use Medisave in Malaysia (Phua and Pocock 2011).

The latest country target of MHTC is New Zealand. MHTC says 2,000 New Zealand medical tourists went to Malaysia in 2014. Almost all went to Kuala Lumpur and Penang, with the vast majority seeking cosmetic surgery or dental treatment. MHTC is promoting weight loss surgery (International Medical Travel Journal, 29 June 2015). According to Seow et al. (2016), geographic region of origin of health travellers is a significant factor in medical tourism participation intention, thus, Malaysia should promote based on geographic region for the sector's competitive advantage in Malaysia.

In 2009, Penang boasted RM162 million in revenue from medical tourism. Medical tourism revenue increased to an estimated RM220 million on the back of an increase in patient numbers of 250,000 , and 90 percent of those were Indonesians in 2010. The industry made revenues of RM370M in 2013, up $20 \%$ on 2012. Ferry service between Swettenham Pier in Penang and Langsa in Acheh, Indonesia, is operated by Langkawi Ferry Services. Prior to this, those residing in Langsa have to travel all the way to Medan or Acheh to catch a flight to Penang; now they have direct access to Penang. Penang is best known within Malaysia for its historical sites, beaches and food. But shopping is also becoming very exciting there. Increased air accessibility provided by Air Asia has facilitated this (Padasian, 2011). Whereas, Johor state claims 27,500 medical tourists in 2012, 31,000 in 2013, and 33,700 in 2014 (International Medical Travel Journal, 29 June 2015).

The number of people coming to Malaysia doesn't necessarily translate into higher revenue as those who come to Malaysia are not as wealthy (BangkokPost, Malaysia eyes medical-tourism crown, 30 July 2014). The health tourism revenue has grown by 30.1 per cent over the last five years (2007-2012) (MPC, 2014). In 2008, Malaysia generated RM299 million in medical tourism revenue. The medical tourism industry generated revenue of about RM777 million in 2014 (Zainal, 2017). Reported by BERNAMA, Malaysia earned further to revenue of RM900 million in 2015, and those figures are expected to rise further to revenue of RM1.3 billion in 2016 ("Govt Aims to Generate RM1.3b from Medical Tourism Industry This Year", 29 March 2016).

In 2014, tourism sector is the second largest foreign exchange earner (after manufacturing), with 27 million tourists, RM72 billion tourism receipts and received RM19 billion of investment. They were 1.77 million workers in tourism sector representing $13 \%$ of workforce. Tourism sector is also the sixth largest contributor to Malaysian 
GDP with $14.9 \%$ of tourist income as a ratio to GDP.

On the other hand, Singapore served around 850,000 patients and took in 1.1 billion Singapore dollars (\$809 million) (Yamasaki, 2015). According to BangkokPost, Thailand and Singapore are targeting those who are really wealthy ("Malaysia eyes medical-tourism crown", 30 July 2014). Though Thailand and Singapore will continue to be larger in terms of dollar size, they are forecasted to see slower growth over the next five years, compared to Malaysia's forecasted CAGR of 18.5 per cent between 2014 and 2020 (Frosty \& Sullivan, 2012).

According to The New Straits Times, Thailand ushered in 2.5 million tourists in 2013 seeking medical treatment ("Malaysia urged to play 'catch-up' in medical tourism field”, 22 June 2014). Thailand's consumers are often from outside the region. Reported in The Malaysian Insider, about a third of those medical tourists come to Thailand from the Middle East, another quarter from Southeast Asia and nearly $15 \%$ from Europe ("World Coup crisis could cost Thailand medical tourism crown", 23 May 2014). The medical tourists in Thailand are from a good selection of countries, like Japan, the United States, United Kingdom and the United Arab Emirates (Amornvivat, 2012). Thailand earned US\$4.31 billion (RM13.84 billion) in revenue from medical tourism in 2013, after average growth of $15 \%$ a year over the past decade as reported in The Malaysian Insider ("World Coup crisis could cost Thailand medical tourism crown", 23 May 2014). Nevertheless, there are issues that may limit the expansion of this medical tourism in Thailand, include (a) lack of government policies and supporting regulations, (b) lack of a cooperation organisation , (c) low awareness of the opportunities of foreign health travellers, and (d) a shortage of medical doctors and other medical staff (Rerkrujipimol and Assenov, 2011).

On Malaysia, past studies has focused on tourism factors contributing to the economic performance, however there is still gap of study on the overall medical tourism decision model of the health travellers. The questions are how importance is medical tourism in economy and what is the decision model. The objective in this study is to study the importance of medical tourism in Malaysian economy and the decision model of medical tourism. This is an important study, as Malaysia is moving forward to keep up with economically more developed economies in the highvalue-added market. In addition, this paper will also provide information to the stakeholders to promote medical tourism as part of a high-income economy, especially its promotion new growth markets.

\section{LITERATURE REVIEW}

The empirical findings between tourism and growth causality in the Malaysian context are showing mix results. Among the literatures that support unidirectional causality from tourism to growth are Lau et al. (2008), Rahman, Affizzah and Edman (2013), 
Tang and Tan (2013) and Tang (2015), and unidirectional causality from growth to tourism are Kadir \& Jusoff (2010), Kadir, Tang (2011), Abdullah \& Nayan (2010b) and Tang (2011c). Literatures that support bidirectional causality are Lean \& Tang (2010), Tang (2011, 2011b) and Cheam, Ismail, Mamat (2013).

Comparing development and government healthcare spending, Cheah and Abdul-Rahim (2014) found long-run relationships from economic development and tourism development to healthcare spending. In contrast, Tang (2012) found that tourist and arrivals have a negative impact on government health care spending.

More recent findings on medical tourism in Malaysia cover different aspects on its impacts and strategies. Tang and Abdullah (2016) indicate that medical tourism has significant positive impact on Malaysia's economic growth in the long run, and Ormond, Wong and Chan (2014) discuss ways to manage medical tourism's advantages and disadvantages. The study of Herberholz and Supakankunti (2013) concludes the importance to understand the business strategies.

Specificallly, Mohamad, Omar and Haron (2012) advance the idea that medical travel facilitators have direct influence on medical tourism. Sarwar (2013) suggests that destination competitiveness and service quality are important in medical tourism, while Manaf, Ghazali and Marikar (2011) argue that equity and access to health services is the foremost concern of healthcare delivery system.

\section{METHODOLOGY}

Qualitative and quantitative methods were applied in this paper. Methods employed include reviewing available literature and policy documents as well as collection of secondary data from sources such as World Bank and Malaysia Health Tourism Council (MHTC). Qualitatively, literature and policy documents were reviewed in order to obtain insight for the analysis of the modified Smith and Forgione (2007)'s Medical Tourism Decision Model in AEC. This will eventually indicate how commercial presence by regional players is integrated into respective national health systems. In this study, the 2010-2015 Malaysian data GDP is the gross domestic product (US\$ Billion), TR (RM Billion) and MTR (RM Million) is the medical tourism receipts were tested quantitatively. In order to test the impact of tourism receipts and medical tourism receipts on gross eomestic products, the natural logarithm of both sides of the equation is taken. Pearson correlation, independent t-test analysis were conducted for testing at $1 \%$ significance level using SPSS 19.

\section{ANALYSIS AND DISCUSSIONS}

Based on data (Figure 1) from MHTC, the number of health travellers and medical tourism income have been in climbing trends in the past 15 years, though there were breaks when the former was negatively affected by the Global Financial Crisis and European Soveireign Debt Crisis. Since the launch of ETP in 2010, the growth of 
medical tourism has been care. accelerated as a part of NKEA health

Figure 1. Number of Health Travellers and Medical Tourism Receipts 20002015

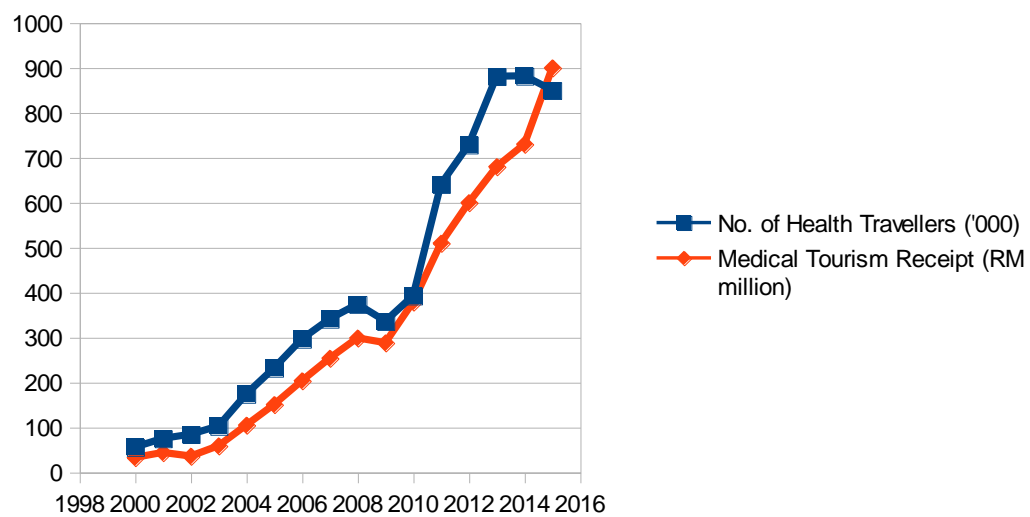

Source: Malaysia Health Tourism Council (MHTC)

Based on data (Figure 2), the gross domestic products (GDP) have been in climbing trends in the past 15 years, though there were breaks when the GDP was negatively affected by the Global Financial Crisis 2009 and global demand slowdown

Figure 2. Gross Domestic Products and Tourism Receipts 2000-2015

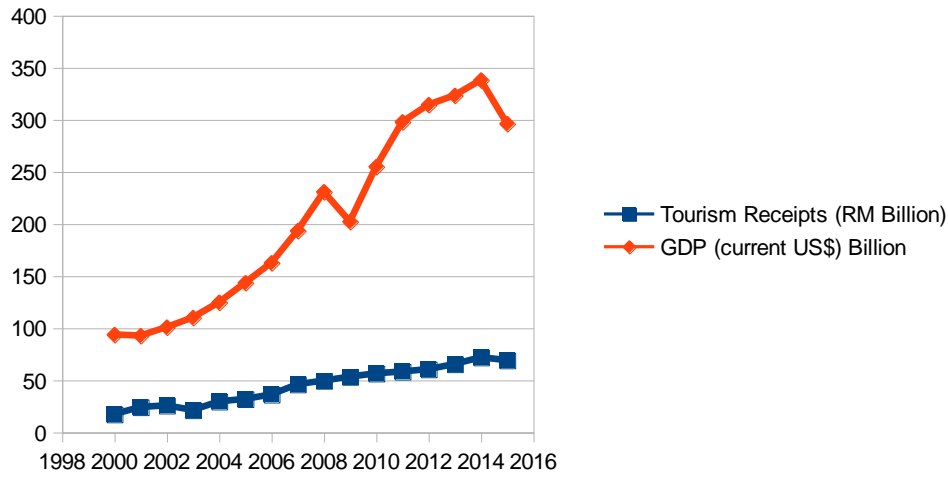

Source: Malaysia Health Tourism Council (MHTC), World Bank Indicators

In order to test the impact of tourism receipts on Gross Domestic Products (GDP), the natural logarithm of both sides of the equation is taken for the corresponding logarithmic equation.
Pearson product-moment correlations were run to determine the relationship between tourism receipt and GDP, and medical tourism receipt and GDP. There was a strong, positive correlation 
between tourism receipt and GDP, which was statistically significant $(r$ $=0.972, p=.001$ ), and there was also a strong, positive correlation between medical tourism receipt and GDP, which was statistically significant $(r=0.981, p=.001)$.
Result of the t-test analysis is obtained, by putting the data from 2000 to 2015, using SPSS 19. For testing at $1 \%$ significance level, the significance results can be seen that increase in tourism receipt is different from the growth in GDP

Table 3. Results of Paired Samples T-Test of GDP and Tourism Receipts

\begin{tabular}{|l|l|l|l|l|l|}
\hline Variables & $\mathbf{n}$ & Mean & SD & T & Sig-t \\
\hline Tourism Receipts & 16 & 3.713 & 0.458 & -54.008 & .000 \\
\hline GDP & 16 & 5.223 & 0.475 & & \\
\hline \\
However the insignificance results can tourism receipt is no different from \\
be seen that increase in medical the growth in GDP.
\end{tabular}

Table 4. Results of Paired Samples T-Test of GDP and Medical Tourism Receipts

\begin{tabular}{|c|c|c|c|c|c|}
\hline Variables & $n$ & Mean & SD & $T$ & Sig-t \\
\hline $\begin{array}{ll}\text { Medical } & \text { Tourism } \\
\text { Receipts } & \end{array}$ & 16 & 5.332 & 1.118 & 0.660 & .519 \\
\hline GDP & 16 & 5.223 & 0.475 & & \\
\hline
\end{tabular}

Further analysis is drawn as

follows: The growth of gross domestic products will increase tourism receipts in Malaysia, which is to say the higher economic growth, the more receipts in tourism.

In addition, the impact of medical tourism on Malaysia's healthcare systems, and the marketing variables of medical tourism are discussed in the following sections.

\section{Development of medical tourism}

The global average for health expenditure is at $9.2 \%$ of GDP. ASEAN countries spend approximately 4 per cent of the total GDP, much less than the global average. Vietnam has the highest share of health expenditure $(6.8 \%)$. On a per capita basis, Singapore spends the highest on healthcare. For almost all countries in ASEAN, the average health expenditure per capita is less than USD400. According to the Malaysian Medical Association (MAA), Malaysia is in the enviable position of being able to control its healthcare cost spending to less than 2.2 per cent of the GDP (compared to the ASEAN average of $10 \%$ ) and yet enjoys health indicators of most developed nations. It's healthcare indicators are a testimony to its efficiency. Life expectancy is 74.6 years, crude death rate is 4.6 per 
1,000 , crude birth rate is 17.1 , and infant mortality rate is 6.6 per 1,000 (Nadaraj, 2014). In 2013, the government allocated RM22 billion (USD6.9 b) to the Minister of Health $(\mathrm{MOH})$. Of the total, $60 \%$ went to pay the salaries of 230,000 employees and $32 \%$ on pharmaceuticals. According the World Health Organisation (WHO), private expenditure on health as a percentage of total expenditure on health was $75 \%$ in 2003, contrasted starkly with government expenditure of $25 \%$ in the same year. Therefore, the implementation of proposed 1 Care for 1 Malaysia, a National Health Insurance System, will lead to universal healthcare coverage (UHC) $(\mathrm{MOH}, 2009)$. On the other hand, demographic shifts on population age structures will increase the burden of healthcare costs; with Malaysia's growing middle aged and elderly population, as well as increased awareness on the importance of healthcare management (Frost \& Sullivan, 2012).

The Economic Transformation Program (ETP) launched in 2010 intended to transform Malaysia into an upper middle-income country. Medical tourism part of the health care National Key Economic Area (NKEA), is intended to generate MYR 4.3 billion in gross national income (GNI) by 2020. It is expected that for-profit hospitals will invest MYR 335 million in hospital infrastructure in order to be prepared for 1.9 million foreign patients annually by 2020 (Pemandu, 2010). The income is expected to grow 15 per cent annually, generating revenue of about RM2 billion for the 11th Malaysia Plan period by 2020 as reported in BERNAMA. ("Govt Aims to Generate RM1.3 billion from Medical Tourism Industry This Year", 29 March 2016). According to TTG Asia, Malaysia is aiming to surpass Thailand and Singapore to become the top medical tourist destination in South-east Asia by 2020 ("Malaysia seeks priority treatment for medical tourism", 3 August 2015).

The Government grants various incentives to the medical tourism industry such as tax exemptions and deductions as well as special permits to promote investment in internationally recognized accreditation schemes e.g. Joint Commission International and Malaysian Society for Quality in Healthcare and state-of-the-art medical equipment.

Health centres unregistered to MHTC would not be entitled for incentives such as the Investment Tax Allowance (ITA) which consists of two parts. Under the Income Tax (Exemption) Order 2012, companies that establish new private healthcare facilities or existing private healthcare facilities undertaking expansion/modernization/refurbish ment for purposes of promoting healthcare travel are eligible to apply for an income tax exemption equivalent to ITA of 100 percent on the qualifying capital expenditure incurred within a period of 5 years. The second par is double tax deduction for accreditation. Besides, the government also gives private hospitals treating foreign patients' benefits such as lower import duties 
and an increased rate of depreciation (from 25 per cent to 40 per cent) for life-saving medical equipment.

$\begin{array}{lrrr}\text { Other } & \text { Entry Point } & \text { Projects } \\ \text { (EPPs) are } & \text { medical } & \text { business } \\ \text { opportunities } & \text { in } & \text { device }\end{array}$
manufacturing. According to Frost \& Sullivan (2012), the value of medical device sales to healthcare facilities was worth US\$4 billion in 2013 in the major economies of ASEAN, and is projected to more than double by 2019, and ASEAN Economic Community (AEC) provides the opportunity to control healthcare costs by reducing the medical devices imports. Medical devices manufactured in Malaysia include orthopaedic products, dialysers, surgical instruments, medical electrodes, diagnostic radiographic equipment, and ophthalmic lenses. It was reported by BERNAMA that Malaysia had more than 190 medical device manufacturers with investments valued at RM13.2 billion and 57,872 people employed (MIDA approves RM464.6 million investments in medical device industry in Q12015, 15 July 2015). Malaysia is the hub of medical device manufacturing in ASEAN and the industry's reliability is recognised worldwide. Penang as the hub of medical devices production hosts many medical device multinational corporations such as Ambu, B.Braun, Haemonetics, Lake Legion (formerly known as Accellent), St. Jude Medical, Symmetry Medical and Toshiba Medical.

US-based

publication International Living which focuses on global retirement and relocation opportunities had rated Malaysia the top six (and the only one from Asia within the top ten), in its 2017 Global Retirement Index, and Malaysia's healthcare system as the best for the third year in 2017 Global Retirement Index (International Living, 2017, MHTC, 2016a). Malaysia offers excellent, low-cost healthcare, and some of the besttrained surgeons, dentists and specialists in the world. Malaysia has been proclaimed "Medical Travel Destination of the Year" for the second consecutive year in 2016 at the International Medical Travel Journal (IMTJ) Medical Travel Awards (MHTC, 2016b). Malaysia Healthcare won almost half of the 2016 IMTJ Medical Travel Awards given out, including four highly commended awards: International Hospital Highly Commended (Gleneagles Kuala Lumpur), Medical Travel Agency of the Year - Highly Commended (Malaysia Healthcare Travel Council), Best Quality Initiative - Highly Commended (Imperial Dental Specialist Centre) and Excellence in Customer Service Highly Commended (Imperial Dental Specialist Centre). Prince Court Medical Centre was also named No. 1 World's Best Hospitals for Medical Tourists 2013 by Medical Travel Quality Alliance (MTQUA).

$$
\text { Malaysia offers }
$$
comprehensive network of hospitals and clinics, with 88.5 percent of the population living within three miles of a public health clinic or private practitioner, according to statistics quoted on Hospitals-Malaysia.org (Yanos, 2008). In Malaysia, all 
private medical facilities are required to be licensed under the Private Healthcare Facilities and Services Act 1998. Out of over 250 private hospitals in Malaysia ("Malaysia Medical Tourism Figures 2015", 26 July 2016), 137 of private hospitals are listed as members of the Association of Private Hospitals Malaysia (APHM), and 41 private hospitals have been recognised by the Ministry of Health as health tourism hospitals (APHM, 2016).

Private hospitals account for approximately $30 \%$ of all hospital admissions (Ministry of Health Malaysia, 2013), with governmentlinked companies at both federal and provincial levels currently control more than $40 \%$ of commercial hospital beds in Malaysia (Chan, 2014). The three big hospital groups in Malaysia are KPJ Healthcare, IHH Healthcare and Ramsay Sime Darby Healthcare (Leong, 2014).

The New Straits Times reported that KPJ Healthcare aims to increase its revenue from health tourism to RM90 million in 2015 from RM78 million in the year before. (KPJ Healthcare eyes RM90m health tourism revenue in 2015, 24 May 2015). Reported by The Edge Financial Daily, KPJ with over 25 hospitals, has ambitious plans for the medical tourism segment, aiming to grow its revenue contribution to $25 \%$ in 2020 (KPJ eyes higher medical tourism revenue, 27 February 2012). KPJ's medical tourism is spearheaded by the Bandar Dato' Onn Specialist Hospital in Iskandar Malaysia, and it is expected to cause an influx of medical tourists from
Singapore. KPJ's networks spread to Australia, Bangladesh, Indonesia and Thailand.

$\mathrm{IHH}$ Healthcare which owns Parkway Pantai and Gleneagles hospital chains is Asia's largest and the world's second largest health care operator based on market capitalization with key markets in Asia-Pacific, Central and Eastern Europe and the Middle East and North Africa (Lai, 2015). Ramsay Sime Darby is a strategic partnership of Sime Darby Healthcare and Ramsay Healthcare to expand in Asia with current networks in Malaysia and Indonesia.

Other private healthcare service providers are such as Adventist Hospital, Apollo TTDI Medical Centre, Columbia Asia Hospitals, Health Management International's Mahkota Medical Centre, Loh Guan Lye Specialists Centre, Petronas' Prince Court Medical Centre, Raffles Medical Group's Island Hospital, Sunway Medical Centre, TDM Berhad, and TMC Life Sciences. In addition, Malaysia's BP Healthcare Group as Southeast Asia's largest medical diagnostic chain, has planned investment of RM50 million for its $6^{\text {th }}$ and $7^{\text {th }}$ specialist centres located in Skudai and Penang as reported in The Star. ("BP Healthcare to invest RM50m in 2 new specialists centres", 4 March 2014).

\section{Marketing variables of medical tourism}

Horowitz and Rosensweig (2007) provide 5 reasons patients seek care at medical tourism destinations: low cost, avoid waiting 
lists, procedure not available in home country, tourism and vacations, and privacy and confidentiality.

The total number of medical tourist arrivals in Malaysia is backed by factors, such as availability of good healthcare infrastructure, government support through promotional programs, and wellskilled medical professionals (Market
Reports Online, 2014). According to the Penang Health Association reported in The Star, the majority of medical tourists visiting Penang are of Indonesian origin, who select Penang because of its proximity (to north Sumatra), convenience of travel, and ease of cultural and language adaptation. ("Malaysian medical tourism growing", 14 February 2010)

Figure 3. Medical Tourism Model of Effective Branding for Better Marketing Note: Modification from Smith and Forgione (2007)'s Medical Tourism Decision Mode

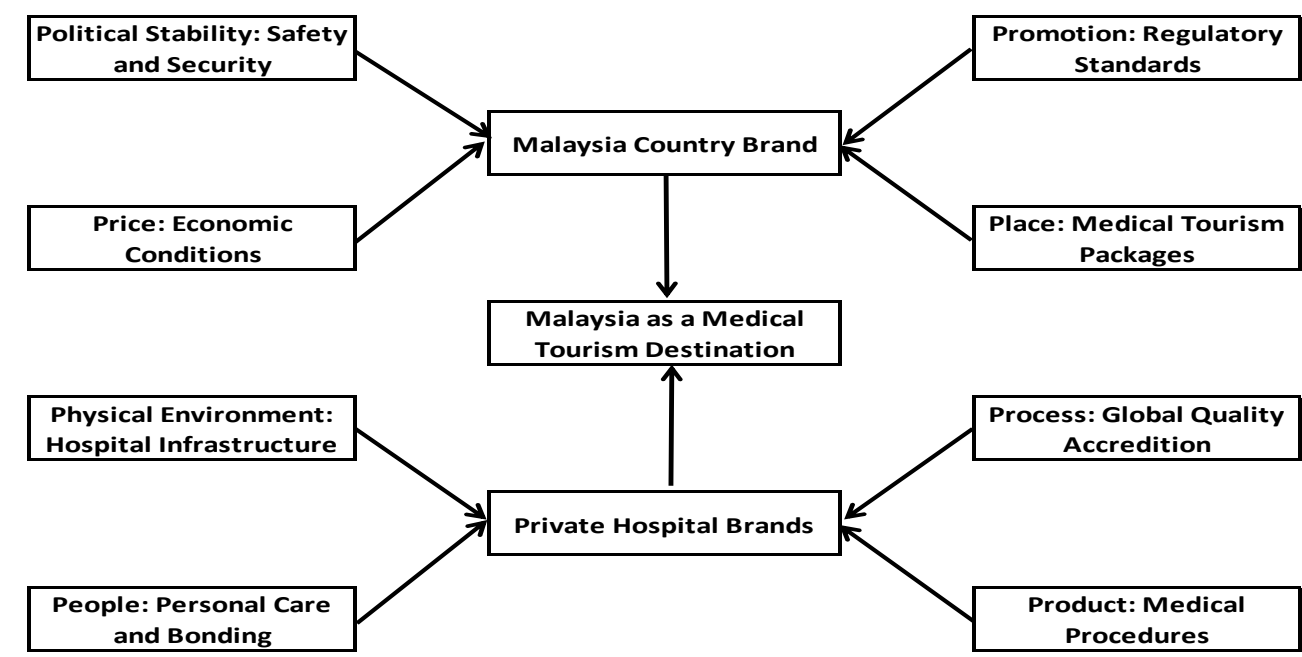

Medical tourism is a new form of a niche tourism market and the rapid growth of international healthcare results from people from all around the world are traveling to other countries to obtain general medical surgery, cosmetic plastic surgery and dental surgery at a fraction of the cost of healthcare in their home country (Meeprom \& Putachot, 2013). Most medical tourists are healthy people who need checkups, individuals requiring heart or cancer operations, and those seeking cosmetic surgery or dental implants. A country with a stable government and ample tourist attractions is bound to be more appealing to patients and their families (Yamasaki, 2015).

The private healthcare industry is encouraged to attract more medical tourists into Malaysia. In these situations, Kotler Seven P's Marketing mix strategies, namely product, price, place, promotion, people, process and physical environment, may be used to fulfil the patient's needs, promote Malaysia's medical tourism branding by healthcare service providers.

The effective branding of Malaysia as a medical tourism destination and private hospitals as 
medical tourism providers can be illustrated in Figure 3. It depicts an abstract of a two-stage model modified from Smith and Forgione (2007) about Malaysia's marketing strategies of medical tourism branding that impacts decision making in seeking medical services globally.

\section{Political Stability}

According to Černikovaitè and Mameniškis (2015), medical tourists prefer areas with stable political environment. In response, the Government of Malaysia has established MHTC to provide services to medical toursuch as safety standards (Wong, Teo and Yap, 2013).

\section{Product}

Private hospitals in medical tourism can function as a diagnostic centre for health screening and follow-ups in medical treatments. The cutting-edge technology made available by these hospitals is one of the major products in medical tourism. Availability of essential procedures is important to accommodate the needs of medical travelers who intend to avoid waiting lists in home countries.

Another attraction of Malaysia as a popular medical tourism destination is the availability of Western and Eastern medical techniques e.g. Traditional and Complementary Medicine (TCM). Malaysia as a member of Organisation of Islamic Countries (OICs) and a global halal hub has increasingly attracting medical travellers from the Middle East. The
Halal Industry Development Corporation projects a big market for halal pharmaceutical products and Malaysian hospital pharmacies can inform patients of halal pharmaceutical products.

Another strategy applied by healthcare service providers is to create more value-added services. These non-medical care services are such as, on-line services for medical arrangement, travel arrangements, medical transportation, provision in major languages, service apartments for patients' relatives, hotel reservation, sightseeing tour services, nursing care serviced, etc. Private hospitals develop cooperation with related organisations e.g. government, travel agencies, hotels, property developers and after-care nursing homes. The capital city, Kuala Lumpur was also recently ranked No 2 best shopping city in Asia Pacific by the Globe Shopper Index.

\section{Price}

Malaysia ranked the $25^{\text {th }}$ on travel and tourism competitiveness index while her most competitive pillar was the price pillar which was ranked the $6^{\text {th }}$ in the world (World Economic Forum, 2015). According to Deloitte, Malaysia is ideal for regular/recurring treatments and moderate complexity cases with a good balance between high quality treatments at competitive prices. Comparing the average stateside costs of selected medical procedures between Asian countries and the United States, Patients Beyond Borders estimates savings in Thailand at 50-75\%, Malaysia at 65- 
$80 \%$, India at $65-90 \%$ and South Korea at 30-45\% (Yamasaki, 2015), and it shows that Malaysia is relatively competitive with Thailand and other countries. Though, Rahman (2010) found merely weak evidences of positive causal influences of relative costs on outbound US medical tourism.

Popular medical procedures in Malaysia include eye surgeries, orthopedics, cosmetic, urology, neurology, rheumatology, endocrinology, obstetrics and gynecology, oncology, and cardiology (Market Reports Online, 2014). These medical procedures are widely available, and two examples of centres of excellence are Institute Jantung Negara and the Nilai Cancer Institute.

Malaysia has actively promoted their healthcare services to international patients since the Asian currency crisis of 1997 as an effective way to bring in foreign funds. Recently, the Malaysian Ringgit (MYR) Valuation has weakened to 4.3 against the USD on $7^{\text {th }}$ September 2015 from 3.50 in the beginning of 2015, to Asia Financial Crisis level.

Reported in the Daily Korean Press, for Malaysia, the Mecca of cosmetic surgery is Penang because there they have a holiday after the incisions have been made (Malaysia a hub for Medical Tourism, 14 January 2014). Medical travellers find that it is still cheaper to have a medical procedure done in Malaysia, even while paying for travel and accommodations than in their home countries. Consequently, Malaysia's medical tourism service providers have a competitive advantage due to its high standard of medical services at a very competitive price.

Place

Informative web-based marketing of hospitals creates awareness of the availability of medical treatments. Information on treatments, facilities, quality assurance other related services available at the websites attract medical travellers. These private hospitals are located in cities concentrated mainly in states such as Penang, Selangor / Kuala Lumpur and Johor.

Closer to Malaysia is an ASEAN market that is 600 million populations strong. There is a lot of potential in ASEAN with a growing middle-class segment that can afford private healthcare. Further away is 5 -flight radius catchment for medical tourism from major cities such as Penang, Kuala Lumpur, and Johor suggests Asian economic giants like China and India could be new target markets.

\section{Promotion}

MHTC together with private hospitals participate in international tourism events e.g. travel marts, travel fairs, exhibitions, seminars, conferences, and advertise in travel magazines. In addition, other informative materials such as brochures, booklets, video compact discs (VCDs) and paper bags were also distributed to create awareness of the healthcare services. The medical tourism hospitals and promotion agencies have been using both the online and offline 
promotion tools to create awareness of the availability of high quality medical care in Malaysia to potential international health travellers. Moreover, some healthcare service providers in Malaysia establish cooperation with the institutes of higher learning, universities and medical schools to establish collaboration in education, exchange of knowledge and training.

\section{People}

Having specialized and qualified doctors and staffs gives a competitive advantage for the hospitals. Encouraging foreign specialists to practice in the hospitals in Malaysia could also boost both the medical tourism sector. In additional, a click on MHTC website reveals that the website provides language options apart from English - Chinese, Arabic, Indonesian and Bangladesh languages, supported by MHTC care line (call centre) with skype call and e-mail. This is due to the fact that many medical travellers chose Malaysia because of the similar culture and language, and on top of short travelling distance. Therefore, private hospitals support health professionals (e.g. doctors, nurses and paramedics) to enhance skill and expertise including bilingual or trilingual language abilities and empower the communication. Private hospitals have medical staffs who speak foreign languages such as Korean, Arabic and Japanese to help patients from these countries.

Frosty and Sullivan (2012) noted Malaysia has a higher-thanaverage availability of medical personnel and high quality facilities providing treatments across the cost spectrum, making it an attractive destination for medical tourists. They are 5,000 medical graduates from domestic and overseas (UK, Australia, etc.) annually, and these doctors have to undergo three years of compulsory government houseman service. Other medical professional graduates entering the healthcare workforce each year are 15,000 nurses, thousands of lab technicians and physiotherapists (Nadaraj, 2014).

The growth of the number of medical professionals has been impressive over the last few years, with the high six-year average growth rates for pharmacists at 20.8 percent, nurses at 13.1 percent, Doctors at 12.8 percent and dentists at 9.2 percent. On the medical professionals to population ratios, the rate of change has been improving across the four key professions over the last seven years. The rate of change is highest for pharmacists at -7.7 percent followed by doctors (-5.8 percent) nurses (-5.1 percent) and dentists (4.1 percent) (MPC, 2014).

Nevertheless, further comparative analysis as in World Bank Indicator, there is still room for improvement as the ratios are still far from the high income economies. The ratio for doctors at 1:758 (2012) is above the world's average at 1:710. Here we are and even better than the middle-income economies at 1:806, but we are still far from the high-income economies like Australia, United Kingdom and the United States of America. As for 
nurses, the ratio at 1:345 (2012) is better than the world's average at 1:351 and even better than the middle-income economies at 1:449, but again when compared with high income economies, we are still a long distance away (MPC, 2014). Malaysia is now targeting targeted 1 : 400 doctor and 1:200 nurse population ratios by the year 2020 .

Competition for talent escalates once the gates of the ASEAN Economic Community (AEC) open on 31 December 2015. Riding on past success, Malaysia has to produce adequate numbers of specialist doctors to satisfy even growing medical needs in term of quality. 60 per cent of specialists were in the private sector as of 2008 $(\mathrm{MOH}, 2010)$. In the meantime, foreign doctors may practice in Malaysia once they have registered with the Malaysian Medical Council and passed a six-month probation during the course of which they have to work under the supervision of a Malaysian specialist (Dahlui \& Aziz, 2011). This could realize the country's hopes of becoming the medical hub of ASEAN.

On the other hand, Chee (2010) alerts that when the private healthcare services in Malaysia are enlarged by the demand of medical tourists, they start a chain reaction, drawing medical expertise from the public sector, which in turn recruits from other, usually poorer, countries. As such, the author suggest that those concerned with issues of equity should urge a deeper examination of the effects on social security and healthcare entitlements, so as to understand the social costs as well. Kangas (2010) demonstrates that relying on treatment abroad may result in suboptimal outcomes for home health systems. Alsharif et al. (2010) suggest that access to health care for poorer groups will worsen in host countries as medical tourism increases, at least in the short term.

\section{Process}

In terms of ease of processes, the Malaysian Healthcare Travel Council (MHTC) has launched its lounge and concierge service in major entry airports such as Kuala Lumpur International Airport (KLIA) and Penang International Airport (PIA). These one-stop centres are to boost and develop medical tourism by providing a continuous healthcare travel experience. Medical tourists entering Malaysia on emergency via 'Visa-on-arrival (VOA)' are allowed to convert to social visit pass (Razak, 2009), and MHTC renders assistance for the visa extension from the Immigration Department. As for logistics, permits are issued to allow medical tourism hospitals to ferry patients to and from the airport or seaport to the respective hospitals and hotels (Razak, 2009).

In terms of quality, the government must safeguard the confidence of the health travellers with high standards of healthcare services in order to maintain high level of patient satisfaction. It must also be incorporated for private hospitals to attain the accreditation/standard to reassure the quality of treatments. According to the Association of Private Hospitals Malaysia (APHM), the 
Malaysian Society for Quality in Health (MSQH) has been given a special allocation by $\mathrm{MOH}$ for the accreditation activities of private hospitals in 2005. Among the 113 registered APHM members, 33 of their members have the local Malaysian Society for Quality in Healthcare (MSQH) accreditation. The Joint Commission International $(\mathrm{JCl})$ is an arm of the organisation that accredits American hospitals participating in Medicare. The $\mathrm{JCl}$ recognizes and accredits that the standard of the hospital meets or exceeds the standard of medical facilities.

In 2015, at least 13 healthcare service providers in Malaysia and 44 in Thailand had $\mathrm{JCl}$ accreditation, whereas there are now 21 healthcare service providers in Singapore and 20 in Indonesia. Malaysian hospitals such as Gleneagles Kuala Lumpur, KPJ Penang Specialist Hospital, Normah Medical Specialist Centre, Pantai Hospital Kuala Lumpur, Penang Adventist Hospital and Subang Jaya Medical Centre are $\mathrm{JCl}$ accredited. Therefore, it is important for Malaysia to focus on hospital quality and reaching for the $\mathrm{JCl}$ international accreditation with efficient and effective healthcare services. In addition, professionalism must also uphold the patient's privacy and confidentiality. Physical environment

Large private hospitals in Malaysia have a good ambience in their infrastructures with spacious, luxury rooms and excellent amenities for patients, and also are equipped with state-of-the-art technology. This is a competitive advantage to obtain the confidence and attract medical travellers to come to Malaysia.

\section{CONCLUSIONS}

Given the importance of medical tourism to the nation's economy the quantitative objective of this paper is to analysis the correlation of tourism and medical tourism receipts in relation to economic grwoth in Malaysia. The qualitative objective of this paper is to analysis the Medical Tourism Decision Model in relation to enhancing the competitiveness of the medical tourism sector in Malaysia within AEC.

Within AEC, Malaysia has just started aggressive promotion of medical tourism in the last two decades. The results of empirical analysis indicates that the more receipts in tourism, the higher in economic growth.

Having good tourism infrastructure and being a relatively lower cost for many related services, Malaysia is a competitive medical tourism hub in the region. Malaysia is strategically located at the centre of ASEAN region. Neighbouring countries are having challenges and will see slower growth over the next five years; Thailand is facing issues of lacking of supporting government policies and Singapore is having issue of rising costs. Private hospitals are expected to invest in hospital infrastructure and facilities to realise Malaysia's aim to surpass Thailand and Singapore to become the top medical tourist destination in South-east Asia by 2020, to be 
prepared for 1.9 million foreign patients and generating revenue of RM2 billion annually by then.

Higher wages and better employment opportunities in growing medical tourism industry enable countries including Malaysia to attract medical professionals. With AEC, Malaysia needs to prepare for an increased flow of skilled workers and fiercer competition in industries including medical tourism. On the other hand, upcoming opportunities are potential medical travellers from less advanced ASEAN countries such as Cambodia, Laos, Myanmar and Vietnam for treatment. Based on the AEC Blueprint 2025, ASEAN will continue to promote the development of a strong healthcare industry to meet the growing demand for affordable and quality healthcare in the region, and promote sectors with highgrowth potential such as health tourism and e-healthcare services, which will not have negative impact on the healthcare system of each ASEAN Member State (ASEAN, 2015). Malaysia has to differentiate the medical tourism products to further develop as a preferred medical tourism destination.

\section{IMPLICATION/LIMITATION SUGGESTION}

AND

This paper has summarised some of the medical tourism promotion strategies. Promotion of Malaysia Country Brands along private hospital brands are both essential. Thus far, MHTC and the healthcare industry in public-private partnership (PPP) have taken steps in promoting and fostering medical tourism as a foreign exchange earner. Despite, Malaysia has yet to be at par with her competing neighbouring countries Thailand and Singapore. Growth of medical tourism should not lead to 'brain drain', but rather 'brain gain' where Malaysian medical specialists who are working abroad are enticed to return home and serve the medical tourist sector. Furthermore, efforts should also be made to encourage the linkage between the healthcare industry, the tourism sector and supporting industries such as medical device and upgrading of the cluster. Therefore, higher standards and quality of treatments must be maintained. It is also essential to provide sufficient tax incentives and import duty reduction on medical equipment to improve Malaysia's competitiveness in this sector. Lastly, for the qualitative analysis of this paper on top of limited length of data for quantitative analysis, the findings should be interpreted with caution.

\section{ACKNOWLEDGEMENT}

This study was funded by 2016 Southeast and South Asia and Taiwan Universities (SATU) Joint Research Scheme hosted by National Cheng Kung University.

\section{REFERENCES}

Alsharif, M.J., Labonté, R. and Lu, Z.X. (2010). Patients beyond borders: A study of medical tourists in four countries. Global Social Policy. 10(3): 315-335.

ASEAN (2015). ASEAN Economic Community (AEC) Blueprint 2015. Available

from 
http://www.asean.org/storage/i mages/2015/November/aecpage/AEC-Blueprint-2025-

FINAL.pdf

Association of Private Hospitals of Malaysia (APHM) (2016). APHM Members (as of June 2016). Available from http://www.hospitalsmalaysia.org

Bookman M, Bookman K. (2007). Medical tourism in developing countries. New York: Palgrave MacMillan.

Brinker, B. and Ong, Q.Y. (2014). IHH Healthcare: A Global Name in Medical Tourism. Shares Investment. 5 May 2014. http: / / www.sharesinv.com/articl es/2014/05/05/ihh-healthcare-aglobal-name-in-medical-tourismpart-1/

BP Healthcare to invest RM50m in 2 new specialists centres. (2014). The Star. 4 March 2014.

Černikovaitè, M.E. and Mameniškis, M.J. (2015). Medical Toourists' Expectations when Choosing Lithuania for Health Care Services. Social Transformations in Contemporary Society. 3, 2439.

Chan CK. (2014). The Malaysian health system in transition: the ambiguity of public and private. MSP Occasional Paper, Queen's University.

Cheah, Chan-Fatt, Abdul-Rahim, A.S. (2014). Tourism, Health and Income in Malaysia. SHS Web of Conferences 12, 01039.

Cheam, C.L., Nik Ismail, N.N.H. and Mamat, M. (2013). The Effect of Tourism Receipts on Economic Growth. The Global Conference on Business, Economics and Social Sciences (GBSR 2013).

Chee, Heng Leng (2010). Medical tourism and the state in Malaysia and Singapore. Global Social Policy. 10(3), 336-357. DOI: 10.1177/1468018110379978.

CIMB ASEAN Research Institute (CARI). (2013). Lifting-thebarriers roundtable: Healthcare, Network ASEAN Forum 2013. Coup crisis could cost Thailand medical tourism crown. (2014) The Malaysian Insider. 23 May 2014. Available from: http: / /www.themalaysianinsider. com/world/article/coup-crisiscould-cost-thailand-medicaltourism-crown

Coup crisis could cost Thailand medical tourism crown. (2014). The Malaysian Insider. 23 May 2014. Available from: http:/ / www.themalaysianinsider. com/world/article/coup-crisiscould-cost-thailand-medicaltourism-crown

Frost and Sullivan (2012). Independent Market Research on the Global Healthcare Services (HCS) Industry, 1 June 2012.

Ganesan, V. (2007). Tapping health tourism. New Straits Times. 21 May 2007.

Govt Aims to Generate RM1.3 billion from Medical Tourism Industry This Year (2016). BERNAMA. 29 March 2016

Herberholz, C. and Supakankunti, S. (2013). Medical Tourism in Malaysia, Singapore and Thailand Horowitz, M.D. and Rosensweig, J.A. (2007). Medical Tourism - Health Care in the Global Economy. The 
Physician

Executive.

November/December.

InternationalLiving.com (2017). The World's Best Places to Retire In 2017. 5 January 2017. Available from

https: / / internationalliving.com/2

017/01/the-best-places-to-retire/ Irsyad, A. (2016). We Are Now Ranked 3rd, But It Is Possible For Malaysia To Become The No. 1 Choice For Medical Tourism Here's Why. Malaysian Digest. 20 January 2016.

Kadir, N., Abdullah, M. S., and Nayan, S. (2010). The causal relationship between tourism and economic growth in Malaysia: Evidence from multivariate causality tests. Tourism and Management Studies, 6.

Kadir, N., and Jusoff, K. (2010). The cointegration and causality tests for tourism and trade in Malaysia. International Journal of Economics and Finance, 2(1), 138143.

Kangas, B. (2010). The burden of pursuing treatment abroad: Three stories of medical travelers from Yemen. Global Social Policy. 10(3): 306-314. DOI: $10.1177 / 1468018110379990$.

KPJ eyes higher medical tourism revenue. (2012). The Edge Financial Daily. 27 February 2012.

KPJ firmly set on expansion plans. (2013). Thr Borneo Post. 24 July 2013. Available from: http:/ /www.theborneopost.com/ 2013/07/24/kpj-firmly-set-onexpansion-plans/

KPJ Healthcare eyes RM90m health tourism revenue in 2015. New Straits Times. 24 May 2015.
Lai, I. (2015). Demand for healthcare seen to remain robust. The Star. 25 March 2015.

Lau, E., Oh, S.-L., \& Hu, S. S. (2008, Auguest 6). Tourist arrivals and economic growth in Sarawak. Retrieved May 30, 2010, from Munich Personal RePEc Archieve (MPRA):

http: / / mpra.ub.unimuenchen. de/9888/1/MPRA_paper_9888.pdf

Lean, H. H., and Tang, C. F. (2010). Is the tourism led growth hypothesis stable for Malaysia? A note. International Journal of Tourism Research, 375-378.

Lee, JH, Kim, HB (2015). Success factors of health tourism: cases of Asian tourism cities. International Journal of Tourism Cities, 1(3), $216-233$.

Leong, T. (2014). Malaysia tries to parlay appeal to Muslim visitors into medical tourism push. Reuters. 29 July 2014. Available from:

http: / /www.reuters.com/article/ 2014/07/29/malaysia-medicalidUSL4NOPO01P20140729

Malaysia: A hub for Medical Tourism. (2014). Daily Korean Press. 14 January 2014. Available from: http://e.koreanpress.net/print_p aper.php?number=1511\&news_art icle=nm_news_article\&target $=p r i$ nt_paper

Malaysia continues to attract more medical tourists from GCC countries. (2014). Oman Observer. 8 September 2014

Malaysia eyes medical-tourism crown. (2014). Bangkok Post. 30 July 2014. Available from: http://www.bangkokpost.com/m 
ost-recent/423241/malaysia-eyesmedical-tourism-crown

Malaysia has great potential in medical tourism. (2012). The Star. 26 September 2012.

Malaysian medical tourism growing. (2010). The Star. 14 February 2010.

Malaysian Productivity Corporation (MPC). (2014). Healthcare Industry Value Chain. Available from

http: / /www.mpc.gov.my/mpc/im ages/file/RR2014/Healthcare\%20R eport/chap2.pdf

Malaysia urged to play 'catch-up' in medical tourism field. New Straits Times. 22 June 2014.

Market Reports Online (2014). Malaysia Medical Tourism Analysis \& Forecast 2014, Industry Research Report. 6 June 2014. Available from http://www.prnewswire.com/ne ws-releases/medical-tourismindustry-in-singapore-andmalaysia-forecast-in-new-marketresearch-reports-262096181.html Malaysia Healthcare Travel Council (MHTC) (2013). The first Medical Tourism Concierge and Lounge in Malaysia. Available from: http://www.mhtc.org.my/en/pre ss-release.aspx [cited 2 August 2014].

Malaysia Healthcare Travel Council (MHTC) (2016). Healthcare Travellers between 2011-2015. Available from https://www.mhtc.org.my/

Malaysia Medical Tourism Figures 2015 (2016). International Medical Travel Journal. 26 July 2016. Available from https://www.imtj.com/news/mal aysia-medical-tourism-figures2015/

Malaysia Healthcare Travel Council (MHTC) (2016a). Malaysia features Healthcare Travel at the 16th Kazakhstan International Tourism Fair. 21 April 2016. Available from

https: //www.mhtc.org.my/malay sia-features-healthcare-travel-atthe-16th-kazakhstaninternational-tourism-fair/

Malaysia Healthcare Travel Council (MHTC) (2016b). Malaysia Tops Healthcare Travel Awards For Second Consecutive Year. May 26, 2016. Available from https://www.mhtc.org.my/malay sia-tops-healthcare-travelawards-for-second-consecutiveyear/

Malaysia seeks priority treatment for medical tourism. (2015). TTG Asia, 3 August 2015.

Manaf, N.H.A., Ghazali, R.J.M., and Marikar, K. (2011). Positioning Malaysia in Medical Tourism

MHTC to Boost Malaysia's Health Tourism Industry. (2015). BERNAMA. 30 May 2015.

Mohamad, W.N., Omar, A, and Haron, M.S. (2012). The Moderating Effect of Medical Travel Facilitators in Medical Tourism. Procedia - Social and Behavioral Sciences. International Congress on Interdisciplinary Business and Social Science 2012 (ICIBSOS 2012). 65, 358 - 363.

MIDA approves RM464.6 million investments in medical device industry in Q12015. (2015). BERNAMA. 15 Jul 2015.

Ministry of Health (MOH) (2002) Malaysia's Health 2002: Technical 
Report of the Director-General of Health. Malaysia: Malaysia Ministry of Health.

Ministry of Health (MOH) (2005). Annual Report. Malaysia: Malaysia Ministry of Health.

Ministry of Health (MOH) (2009). Concept Paper. 1Care for 1Malaysia. Restructuring the Malaysian Health System. Malaysia: Ministry of Health, Malaysia.

Ministry of Health (MOH) (2013). Health facts 2013. Available from:

http://www.moh.gov.my/images /gallery/publications/HEALTH FACTS 2013.pdf [cited 2 August 2014].

Nadaraj, V. (2014). Malaysia's Healthcare Tourism: The Path is Paved with Gold. The Establishment Post. 9 April 2014.

NTP: Malaysia generates RM588 million in healthcare travel revenue. AstroAwani.com, 27 April 2016. Available from http://english.astroawani.com/m alaysia-news/ntp-malaysiagenerates-rm588-millionhealthcare-travel-revenue-103794 Ormond M. (2013). Neoliberal governance and international medical travel in Malaysia. Abingdon: Routledge.

Ormond M. and Sulianti D. (2014). More than medical tourism: lessons from Indonesia and Malaysia on South-South intraregional medical travel. Curr Issues in Tourism.

Ormond, M., Wong, K.M. and Chan, C.K. (2014) Medical tourism in Malaysia: how can we better identify and manage its advantages and disadvantages? Global Health Action, 7(1), 25201

Oxford Business Group (2015). A global leader: Rising medical tourism points to the industry's strengths.

http: / /www.google.com.my/url?s $a=t \& r c t=j \& q=\&$ esrc $=s \& f r m=1 \&$ sou rce=web\&cd $=1 \& v e d=0 C B w Q F j A A a$ hUKEwig_vHez8PHAhUPjo4KHTJX C_A\&url=http\%3A\%2F\%2Fwww.oxf ordbusinessgroup.com\%2Fovervie w\%2Fglobal-leader-rising-medicaltourism-pointsindustry\%25E2\%2580\%2599sstrengths\&ei=bQ3cVeATj5y6BLKur YAP\&usg=AFQjCNEuNF3h9fHOCVJgGqq2fLOwOHOzA

Padasian, J. (2011). Penang Medical, Healthcare Magazine. 2011.

PEMANDU (2010). Creating wealth through excellence in healthcare. Available from: http://www.moh.gov.my/images /gallery/ETP/NKEA Penjagaan Kesihatan.pdf [cited 2 August 2014].

Picazo, O. (2013). Medical Tourism in the Philippines: Market Profile, Benchmarking Exercise and S.W.O.T. Analysis. Makati: PIDS.

Ormond, M., Wong, K.M, and Chan, C.K. (2014). ASEAN Integration and Its Health Implications: Medical tourism in Malaysia: how can we better identify and manage its advantages and disadvantages? Global Health Action, 7, 96-99.

Rahman, M. (2010). Outbound US medical tourism to selected Asian countries. International Journal 
of Behavioural and Healthcare Research, 2(1), 75 - 84.

Rahman, Affizzah and Edman (2013). Impact of Tourist Arrival in Economic Growth: Empirical Evidence from Malaysia. GBSR eJournal of Business, Economics and Social Sciences Research 2013.

Razak, M.N.(2009). Malaysia Healthcare Travel Council Speech Text. Official Launching of Malaysia Healthcare Travel Council. 21 December 2009. Retrieved December 22, 2009 from http://www.pmo.gov.my/?menu= speech\&news_id=182\&page $=1676$ \&speech_cat\#2

Rerkrujipimol, J. and Assenov, I. (2011). Marketing Strategies for Promoting Medical Tourism in Thailand. Journal of Tourism, Hospitality \& Culinary Arts. 3(2), 95-105.

Sarwar, A. (2013). Medical Tourism in Malaysia: Prospect and Challenges. Iranian J Publ Health, 42(8), 795-805.

Seow, A.N., AuYong, H.N. and Choong, Y.N. (2016). Health Travellers' Behaviour Intention for Healthcare Service Abroad: The Effects of Perceived Benefits, Perceived Risks and Geography Region. The 3rd International Conference on Science and Social Research (CSSR), Putrajaya, 6 \& 7 December 2016.

Smith, P. and Forgionee, D. (2007). Global outsourcing of Healthcare: A Medical Tourism Decision Model. J Inf Technol Case Appl Res, 9(3), 19.
Suleiman, A.B. (2013). Medical Tourism - Malaysia. Regional World Health Summit 2013.

Supapol, A.B., Barrows, D. and Barrows, A. (2007). Canadian Health and Wellness Tourism: Obstacles Impeding International Competitiveness. The Innovation Journal: The Public Sector Innovation Journal, 12(3), Article 12.

Tang, C.F. (2011) Is the tourism-led growth hypothesis valid for Malaysia? A view from disaggregated tourism markets. International Journal of Tourism Research, 13(1), 97-101.

Tang, C. F. (2011a). Temporal granger causality and the dynamics examination on the tourism growth nexus in Malaysia. Retrieved February 14, 2011, from Munich Personal RePEC Achieve: http://mpra.ub.unimuenchen.de/29237/2/MPRA_pap er_29237.pdf

Tang, C. F. (2011b). Tourism, real output and real effective exchange rate in Malaysia: A view from rolling sub-samples. Retrieved July 19, 2011, from Munich Personal RePEC Archive: Tourism, real output and real effective exchange rate in Malaysia: a view from rolling subsamples

Tang, C. F. (2012). Temporal Granger Causality and the dynamics relationship between real tourism receipts, real income and real exchange rates in Malaysia. Int. J. of Tour. Res., 15(13), 272-284

Tang, C. F. (2015). Medical Tourism and Its Implication on Malaysia's 
Economic Growth. MPRA Paper 63365, University Library of Munich, Germany.

Tang, C.F. and Abdullah, A.S.N. (2016). Can inbound medical tourism boost Malaysia's economic growth? Tourism and Hospitality Research. December: 1-9.

Tang, C.F. and Tan, E.C. (2013) How stable is the tourism-led growth hypothesis in Malaysia? A view from disaggregated tourism markets. Tourism Management, 37, 52-57.

Voigt, C. (2009). Understanding Wellness Tourism: An Analysis of Benefits Sought, HealthPromoting Behaviours and Positive Psychological Well-Being. Unpublished PhD Thesis, University of South Australia, Australia.

Whittaker, Andrea (2010).

Challenges of medical travel to global regulation: A case study of reproductive travel in Asia. Global Social Policy. 10(3), 396415.

Wong, J., Teo, R., and Yap, J. (2013) Forays into niche tourism subsectors. Borneo Post. 5 May 2013.

World Economic Forum, WEF (2015).

The Travel and Tourism Competitiveness Report 2015.
Available

from:

http://www3. weforum.org/docs/

TT15/WEF_Global_Travel\&Touris

m_Report_2015.pdf

Yamasaki, D. and Fujiwara, T. (2015). Asia leads a medical tourism industry worth billions. Nikkei Asian Review. 26 February 2015.

Yang, JY, Paek, S., Kim, T., Lee, TH, (2015). Health tourism Needs for healing experience and intentions for transformation in wellness resorts in Korea. International Journal of Contemporary Hospitality Management, 27(8), 1881 - 1904.

Yanos, M. (2008). Top 5 Medical Tourism Destinations. Association of Private Hospitals of Malaysia (APHM). March 31, 2008. Available from: http://www.nuwireinvestor.com/ articles/top-5-medical-tourismdestinations-51502.aspx

Zainal, Fatimah (2017). Malaysia a major draw for healthcare travellers. The Star. 1 February 2017. 